\title{
ISOLATION AND ANALYTICAL CHARACTERIZATION OF LOCAL MALAYSIAN LEECH SALIVA EXTRACTS
}

\author{
Mohamed Aladma ${ }^{1}$, Manar AlnajJar ${ }^{3}$, Abdualrahman M. Abdualkader ${ }^{1}$, \\ ABbas MOHAMMAD ${ }^{2}$ AND AHMED MERzOUK ${ }^{1}$ \\ ${ }^{1}$ Department of Pharmaceutical Chemistry, \\ ${ }^{2}$ Department of Basic Medical Science \\ Kulliyyah of Pharmacy, International Islamic University Malaysia. \\ Kuantan, Malaysia. \\ ${ }^{3}$ Kulliyyah of Pharmacy, Aleppo University, Aleppo, Syria. \\ hass83pharm@yahoo.com
}

\begin{abstract}
Leech saliva contains biologically active compounds that are mainly proteins and peptides. In this study a modified and smooth extraction method of saliva was used without leeches' scarification. UV and Bradford Assay protein methods showed that the saliva extract contains high concentrations of proteins. RP-HPLC chromatogram revealed that more than 30 different peaks were observed in leech saliva extract. Gel electrophoresis revealed the existence of proteins and peptides with different molecular weights. The gel showed up to 25 different bands. Comparison of gel electrophoresis data with protein database revealed the closeness of four molecular weights to known proteins from Hirudinaria leech family. Other proteins detected by gel electrophoresis may be related to completely new biologically active proteins and peptides in the saliva extract or to a modification (isoforms) of the existing ones or finally to a mixture of both.
\end{abstract}

ABSTRAK: Air liur pacat secara biologinya mengandungi sebahagian besar campuran aktif protein dan peptida. Dalam kajian ini, kaedah pengestrakan air liur pacat yang telah diubah suai digunakan tanpa perlu membunuh pacat. Kaedah protein Cerakin $U V$ dan Bradford menunjukkan air liur pacat yang diekstrak mengandungi konsentrasi protein yang tinggi. Kromatogram RP-HPLC memperlihatkan lebih daripada 30 puncak berbeza diperolehi semasa air liur pacat diekstrak. Gel elektroforesis memperlihatkan kewujudan protein dan peptida dengan berat molekul yang berbeza. Gel menunjukkan hingga 25 jalur yang berbeza. Perbandingan data menggunakan gel elektroforesis seiring dengan pangkalan data protein memperlihatkan persamaan empat berat molekul, dengan protein yang yang dikenali daripada keluarga pacat Hirudinaria. Jenis protein lain yang dikesan dengan menggunakan gel elektrofosis mungkin juga berkait secara biologinya dengan protein dan peptida aktif yang baru, dalam ekstrak air liur atau pengubahsuaian (beberapa jenis yang berbeza daripada protein yang sama) daripada yang sedia ada ataupun gabungan kedua-duanya.

KEYWORDS: leech saliva; RP-HPLC; gel electrophoresis

\section{INTRODUCTION}

Leech saliva extracts have received much attention because the extensive uses in many medical fields [1]. Leech saliva contains active compounds which act as strong anticoagulants [1]. Those anticoagulants almost are proteins and peptides secreted by leeches salivary glands while sucking the blood to prevent it from coagulation [2], and furthermore to keep blood in the liquid statue during the period of storage to achieve easier digestion [3], which may last up to six months [4]. Hirudin is the most known 
anticoagulant compound isolated from leech Hirudo medicinalis [5]. While other species of leeches have been studied and number of proteins and peptides have been found in their saliva extract [6-8].

In Malaysia there are many species of leeches belonging to the tropical leech Hirudinaria manillensis family [9]. A little work has been undertaken to isolate, characterize and subsequently test for active compounds in their saliva extract. The aim of this study is to throw a light and open the door for wider studies on what Malaysian leeches saliva extracts have to offer in term of active peptides and proteins in a much needed medical fields like: oncology, diabetes and infectious diseases. To satisfy this goal, state-of-the art tools of biomedical and analytical methods were used.

Proteomic techniques tools and proteins database searching are applied in this study to have a better understanding of compounds with high molecular weight proteins contained in the leech saliva extract.

\section{MATERIALS AND METHODS}

Leeches were collected from local suppliers around Pahang area, Bradford protein assay reagents (Amresco), all gel electrophoresis reagents were purchased from Bio Rad, peptide marker was purchased from Sigma Aldrich, HPLC grade acetonitrile was purchased from Fisher scientific, HPLC grade water was from Merck.

\subsection{Leech Saliva Extraction}

Leeches were kept in plastic containers containing water at $23^{\circ} \mathrm{C}$ for the period of experiment. Water was changed every three days. Leeches were starved for three weeks. Saliva was obtained by a small variation of a method described in the literature [10]. Briefly, parafilm membrane (Laboratory film Chicago IL 60631) instead of baudruche membrane was stretched across a funnel containing $0.001 \mathrm{M}$ arginine in $0.15 \mathrm{M}$ saline solution. The solution was maintained at $37^{\circ} \mathrm{C}$ and leeches were allowed to suck the solution through the membrane. The weight of leeches before and after sucking was reported. Leeches were allowed to suck until satiation. Directly after leeches drop down from the membrane, they were immobilized by putting them in plastic container surrounded by ice for 5-10 min. This technique forces the leeches to vomit whatever they have sucked. To complete the saliva collection, leeches were squeezed smoothly from the posterior toward anterior (mouth) sucker.

All fluids that have been vomited were collected (bloody fluids were discarded) in clean test tubes and centrifuged at $4^{\circ} \mathrm{C}$ for 10 minutes at $9000 \mathrm{rpm}$, and the supernatant fluid was named leech crude saliva extract.

The following feeding solutions were tested: $0.001 \mathrm{M}$ arginine, in $0.15 \mathrm{M}$ saline; 0.001 $\mathrm{M}$ arginine, $5 \%$ sucrose, in $0.15 \mathrm{M}$ saline; $0.001 \mathrm{M}$ arginine, $5 \%$ mannitol in $0.15 \mathrm{M}$ saline; $0.001 \mathrm{M}$ arginine, $5 \%$ sucrose in distilled water; $0.001 \mathrm{M}$ arginine, $5 \%$ mannitol in distilled water. Most of the mentioned solutions were rejected except $0.001 \mathrm{M}$ arginine in $0.15 \mathrm{M}$ saline which is used for the whole experiment.

\subsection{Estimation of Protein Concentration in Leech Saliva Extract}

Concentration of proteins and peptides in the saliva extract was estimated by using UV absorption and Bradford proteins assay methods. The UV method was performed to estimate proteins concentration at $\mathrm{A}_{280}$ maximum absorption [11]. 
On the other hand, protein concentration was also estimated by using Bradford protein assay method [12] in which bovine-serum albumin (BSA) is taken as a standard in the calibration curve on Greiner 96 Flat Bottom Transparent Polystyrol [GRE96ft.pdfx] at $595 \mathrm{~nm}$ wavelength.

\subsection{Gel Electrophoresis of Saliva Extract}

One dimensional (1D) electrophoresis was carried out according to what have been described by Laemmli [13] using 15\% gel to detect proteins and peptides with molecular weight ranging between 10-90 kDa. To detect small molecular weight of less than $40 \mathrm{kDa}$ the following methods were used: a none urea SDS-PAGE [14]; using 19\% gel, and 16\% gel with tricine SDS-PAGE [15] .

Saliva extract proteins (about $15 \mu \mathrm{g}$ ) and a mixture of peptides marker of $1.02-26 \mathrm{kD}$ (Sigma) were applied using Mini Protein Tetra cell instrument (Bio Rad) and power supplier. Gels (1mm thick) of $6 \times 10 \mathrm{~cm}$ were used for all tests. Coomassie blue staining was carried out according to standard protocol [16]. Gels were scanned using a Bio Rad gel documentation system.

\subsection{RP-HPLC of Saliva Extract}

Fresh and lyophilized saliva extract were dissolved in HPLC water to an estimated concentration of $100 \mu \mathrm{g} / \mathrm{ml}$ for fresh saliva and $1000 \mu \mathrm{g} / \mathrm{ml}$ for lyophilized saliva from which $100 \mu \mathrm{l}$ was taken and injected through an automatic injector connected to an Agilent reversed phase $\mathrm{C}_{18}$ column $(4.5 \times 150 \mathrm{~mm} \times 5 \mu \mathrm{m})$. Buffer A $(0.1 \%$ TFA in water $)$ and buffer B $(0.1 \%$ TFA in acetonitrile) were used as mobile phases. A linear gradient of $5-90 \%$ buffer B over $40 \mathrm{~min}$ is used for the elution. The absorbance detection was fixed at $214 \mathrm{~nm}$.

\section{RESULTS}

\subsection{Leeches Feeding and Saliva Collection}

After three weeks starvation leeches started sucking the phagostimulatory solution. The solution was highly tolerated by leeches. Leeches saliva extract was collected by putting them first in an ice container for $7 \mathrm{~min}$. Leeches were brought close to parafilm membrane (Fig. 1). To complete the extraction, leeches were squeezed smoothly from the posterior toward the anterior (mouth) sucker. The saliva was collected from 140 leeches. The body weight of these leeches ranges between $0.2-7$ grams. The volume of the sucked solution by leeches ranges between $0.9-17 \mathrm{ml}$.

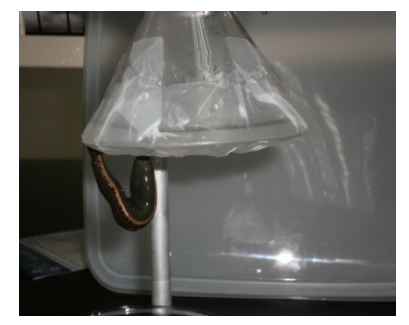

Fig. 1: Leech while sucking the solution through the membrane.

It was observed that some leeches give a bloody saliva extract. The reason was probably due to the blood that still not completely digested in their gut (recently fed). This bloody saliva extract was somehow related the leech body weight. Heavy body mass leeches were more prone to give bloody saliva extracts than the lighter ones. It is 
interesting to observe that the period of starvation did not play an important role in the amount of fluid sucked.

Table 1: Solutions used for leech feeding and their "compatibility".

\begin{tabular}{|c|c|c|}
\hline Solution & No. of leeches & Acceptance \\
\hline Saline 0.15 M + arg 0 .001 M & 5 & $100 \%$ \\
\hline Saline 0.15 M + Arg 0.001 M + sucrose 5\% & 5 & $80 \%$ \\
\hline Saline 0.15 M + Arg 0.001 M + mannitol 5\% & 5 & 0 \\
\hline Mannitol 5\% + Arg 0.001 M & 5 & 0 \\
\hline Sucrose 5\% + Arg 0.001 M & 5 & 0 \\
\hline
\end{tabular}

The best solution to feed leeches was saline $0.15 \mathrm{M}+\operatorname{Arg} 0.001 \mathrm{M}$, leeches still suck the solution after adding sucrose but no more after adding mannitol which seems as inhibitor.

\subsection{Concentration of Saliva Proteins}

The UV absorbance at $\mathrm{A}_{280}$ that has been measured for different leech saliva extracts ranges from 0.159 to 0.521 with a mean of 0.311 and $\mathrm{SD}=0.118$ (Table 2). The protein concentration measured by Bradford method ranges from 39 to $105 \mu \mathrm{g} / \mathrm{ml}$ with a mean of $67.9182 \mu \mathrm{g} / \mathrm{ml}$ and $\mathrm{SD}=29.14 \mu \mathrm{g} / \mathrm{ml}$ (Table 3).

Table 2: $\mathrm{A}_{280}$ for crude saliva extract.

\begin{tabular}{|c|c|c|c|c|}
\hline No & $\begin{array}{c}\text { Number of } \\
\text { leeches }\end{array}$ & $\begin{array}{c}\text { Volume taken from } \\
\text { every leech }(\mathbf{m l})\end{array}$ & $\begin{array}{c}\text { Period of } \\
\text { starvation }\end{array}$ & $\begin{array}{c}\text { Absorbance at } \\
\mathbf{2 8 0 n m}\end{array}$ \\
\hline 1 & 1 & 3 & 3 weeks & 0.218 \\
\hline 2 & 45 & 4 & 4 weeks & 0.241 \\
\hline 3 & 2 & 2.5 & 12 weeks & 0.521 \\
\hline 4 & 5 & 2.5 & 14 weeks & 0.448 \\
\hline 5 & 5 & 5 & 16 weeks & 0.335 \\
\hline 6 & 5 & 17.5 & 18 weeks & 0.159 \\
\hline
\end{tabular}

Table 3: Saliva protein concentration using Bradford method.

\begin{tabular}{|c|c|c|c|c|}
\hline No & $\begin{array}{c}\text { Number of } \\
\text { leeches }\end{array}$ & $\begin{array}{c}\text { Volume taken from } \\
\text { every leech }(\mathbf{m l})\end{array}$ & $\begin{array}{c}\text { Period of } \\
\text { starvation }\end{array}$ & $\begin{array}{c}\text { Concentration } \\
\boldsymbol{\mu g} / \mathbf{m l}\end{array}$ \\
\hline 1 & 19 & 8.2 & 6 weeks & 39.97 \\
\hline 2 & 17 & 1.9 & 9 weeks & 59.2 \\
\hline 3 & 2 & 2.5 & 12 weeks & 105.35 \\
\hline 4 & 5 & 2.5 & 14 weeks & 91.41 \\
\hline 5 & 5 & 17.5 & 18 weeks & 43.661 \\
\hline
\end{tabular}

It has been observed that the proteins and peptides concentration in the saliva extract varies according to the following: 
a) the concentration of proteins and peptides increases by increasing leech starvation. The twelfth week is considered to be the maxima after that the concentration began to decrease. The decrease in the concentration is believed to be related to the leech's exhaustion.

b) the amount of solution sucked by leeches affect the concentration, more solution sucked results in less concentration (dilution factor).

\subsection{Gel electrophoresis of Saliva Extract}

Figures 2A and 2B show typical 1D-electrophoregrams of separation of high molecular weight proteins and peptides isolated from saliva of local Malaysian leeches. One-dimensional electrophoresis revealed the presence of more than 25 proteins and peptides ranging from $3.7-80 \mathrm{kDa}$. These results are obtained side by side with a proteins and peptides standard reference. The diagram shows some coincidence of known proteins and peptides in related species (Table 4) and new bands (new compounds) which are not studied before in Hirudinaria leech family (Table 5).

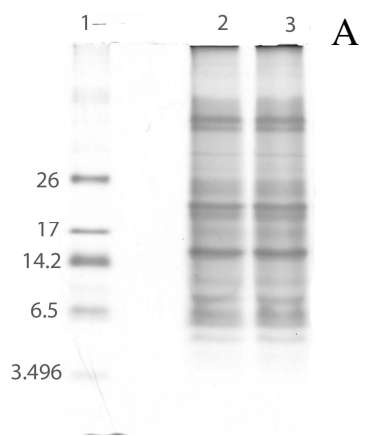

Fig. 2A: Separation of protein components of the medicinal leech saliva by Tricine-SDS-PAGE $16 \%$; lane $1=$ molecular mass markers (in $\mathrm{kDa}$ ); lanes 2$3=$ diluted sample.

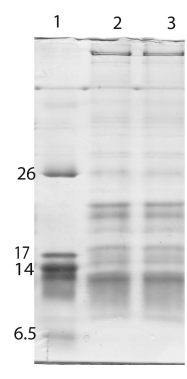

B
Fig. 2B : Separation of protein components of the medicinal leech saliva by SDS-PAGE $15 \%$ : lane 2,3 = lyophilized saliva, lane $1=$ peptide markers (in $\mathrm{kDa}$ ).

Table 4: Isolated proteins from Hirudinaria manillensis.

\begin{tabular}{|c|c|c|}
\hline $\begin{array}{c}\text { Proteins isolated from } \\
\text { Hirudinaria manillensis }\end{array}$ & $\begin{array}{c}\text { Observed molecular } \\
\text { weight (Da) }\end{array}$ & $\begin{array}{c}\text { Calculated molecular } \\
\text { weight (Da) }\end{array}$ \\
\hline Gelin [17] & $8024-8200$ & 8252 \\
\hline Bufrudine [18] & 7000 & 7122 \\
\hline Hrulline P18 [19] & $6600-6800$ & 6616 \\
\hline Manillase [20] & 58000 & 57173 \\
\hline
\end{tabular}

Comparison of molecular masses of high molecular weight components of the Malaysian leech salivary gland secretion revealed by gel electrophoresis with literature data of calculated and experimentally detected molecular weights of proteins produced by the Hirudinaria manillensis leech. 
Table 5: Isolated proteins from other species of leech.

\begin{tabular}{|c|c|c|}
\hline $\begin{array}{c}\text { Proteins isolated from other } \\
\text { species of leeches }\end{array}$ & $\begin{array}{c}\text { Observed molecular } \\
\text { weight (Da) }\end{array}$ & $\begin{array}{c}\text { Calculated molecular } \\
\text { weight (Da) }\end{array}$ \\
\hline HMW bdellins group B3[21] & 20000 & 20717 \\
\hline Calin [22] & 65000 & 64950 \\
\hline Lefaxin [8] & 30000 & 30216 \\
\hline Hyaluronidase [23] & 28500 & 28713 \\
\hline Destabilase lysozyme [24] & 12000 & 12694 \\
\hline
\end{tabular}

\subsection{RP-HPLC of Saliva Extract}

The analytical chromatogram of the crude saliva extract showed the presence of more than 30 peaks with good resolution. This result was the same for fresh and lyophilized saliva extract (Fig. 3) and consistently reproducible with different batches taken at different time interval.

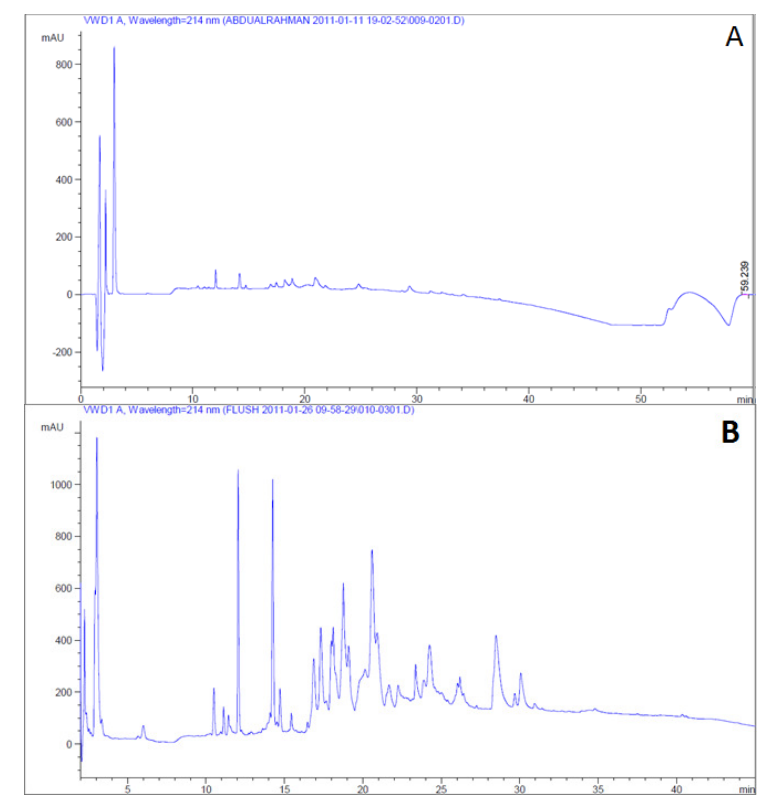

Fig. 3: Sample analysis using RP-HPLC. Column: Agilent C18, buffer A is $0.1 \%$ TFA in water, buffer $\mathrm{B}$ is $0.1 \%$ TFA in acetonitrile, flow rate of $1 \mathrm{ml} / \mathrm{min}$, gradient: $5 \% \mathrm{~B}$ over $5 \mathrm{~min}, 5-90 \%$ B over $40 \mathrm{~min}$, wavelength $215 \mathrm{~nm}$. A= fresh saliva, $\mathrm{B}=$ lyophilized saliva.

\section{DISCUSSION}

In order to have a leech saliva extract with high proteins and peptides concentration one need to starve leeches for a period of time [25]. The optimum period was found to be between 3 weeks [25], and 16 weeks [26]. In our case three weeks starvation was the initial time for leeches to start sucking the phagostimulatory solution, but with a low proteins and peptides concentration as measured by UV and Bradford methods. A maximum concentration was obtained after 12 weeks starvation period. 
Many methods to study saliva content of different leeches family have been described. The majority of these methods are very invasive and consist of scarifying leeches by grounding and mixing their heads $[2,18]$ or grounding and mixing the whole body [25], or taking out salivary glands by surgery [27]. Other method that still need to scarify the animal, consists of immersing a starved leech in $8 \%$ ethanol which will cause the animal to regurgitate its saliva [28]. One of the very soft method that spares leeches life and in the same time allows the collection of the desired saliva amount from leeches was described [10]. After several attempts, we found that it is much easier to collect the saliva by putting the leeches in ice bath inside a plastic test tube, the freezing temperature causes the animal to regurgitate (vomit) the desired sucked solution and causes the immobilization of its movement which in turn facilitate the squeezing in order to optimize the amount of saliva obtained. Last and not least, the ice does not kill the animal and it is enough to put him again in a warm water to regain all its activity and continue to leave normally for undefined period of times.

Several phagostimulatory solutions were tested, for instance the best result is obtained with $0.001 \mathrm{M}$ arginine in $0.15 \mathrm{M}$ sodium chloride solution. Other solutions were also tested, we found that $5 \%$ of sucrose still gives a good result, but when mannitol is used instead of sucrose, the solution is not accepted by leeches.

The gel electrophoresis reveals the existence more than 25 proteins and peptides in the leech saliva extract. Some of these proteins were also isolated from Hirudinaria Manillensis family as reported in literature. These include manillase [20], bufiridine [18], gelin [17], and hirullin P18 [19].

Other proteins were found to be similar in molecular weight to proteins isolated from other leech species but were not studied in Hirudinaria manillensis family. These include calin [22], lefaxine [8], hyaluronidase [23], HMW bdilline group B-3[21], destabilaselysozyme [24].

The other proteins found in this study may be related to unknown biologically active proteins or modification of known proteins or mixture of both. However the Malaysian leech saliva extracts need more investigation to know its composition and its biological activities.

\section{CONCLUSION}

Leech saliva extract was described using reversed phase HPLC and 1D gel electrophoresis, and the full characterization of all active compounds is underway.

\section{ACKNOWLEDGEMENT}

This research was supported gratefully by the grant (EDW B 10-0393) from ResearchManagement Centre, International Islamic University Malaysia, IIUM.

\section{REFERENCES}

[1] Sawyer, R.T., ed. Leech Biology and Behaviour: Volume II: Feeding Biology, Ecology, and Systematics. 1986. Oxford University Press, USA1986.

[2] Markwardt, F., Die Isolierung und chemische Charakterisierung des Hirudins. HoppeSeyler's Zeitschrift für physiologische Chemie, 1957. 308(Jahresband): p. 147-156.

[3] Wallis, R.B., Hirudins: From Leeches to Man. Seminars in thrombosis and hemostasis, 1996. 22(2): p. 185-196. 
[4] Mann, K.H., Leeches (Hirudinea) their structure, physiology, ecology and embryology. Vol. 11. 1962: Pergamon Press (Oxford and New York) 201.

[5] Hycraft, J.B., The action of a secretion obtained from the medicinal leech on a coagulation of blood. Proc. R. Soc. London 1884. 36: p. 478-487.

[6] Salzet, M., et al., Theromin, a novel leech thrombin inhibitor. J Biol Chem, 2000. 275(40): p. 30774-80.

[7] Nutt, E., et al., The amino acid sequence of antistasin. A potent inhibitor of factor Xa reveals a repeated internal structure. The Journal of biological chemistry, 1988. 263(21): p. 10162-7.

[8] Faria, F., et al., A new factor Xa inhibitor (lefaxin) from the Haementeria depressa leech. Thrombosis and haemostasis, 1999. 82(5): p. 1469-73.

[9] Fredric R. Govedich, W.E.M.a.R.W.D., Euhirudinea (leeches). In: Freshwater Fauna of Malaysia and Borneo, in Fresh Water Invertebrate of the Malaysian Region C.Y. and .Y.H. Sen, Editor 2004, Academy of Sciences Malaysia Publishing. p. 175-190.

[10] Rigbi, M., et al., The saliva of the medicinal leech Hirudo medicinalis--I. Biochemical characterization of the high molecular weight fraction. Comparative biochemistry and physiology. B, Comparative biochemistry, 1987. 87(3): p. 567-73.

[11] Aitken, A. and M. Learmonth, Protein Determination by UV Absorption, in The Protein Protocols Handbook, J.M. Walker, Editor 1996, Humana Press. p. 3-6.

[12] Bradford, M.M., A rapid and sensitive method for the quantitation of microgram quantities of protein utilizing the principle of protein-dye binding. Analytical biochemistry, 1976. 72: p. 248-54.

[13] Laemmli, U.K., Cleavage of structural proteins during the assembly of the head of bacteriophage T4. Nature, 1970. 227(5259): p. 680-5.

[14] Okajima, T., T. Tanabe, and T. Yasuda, Nonurea sodium dodecyl sulfate-polyacrylamide gel electrophoresis with high-molarity buffers for the separation of proteins and peptides. Anal Biochem, 1993. 211(2): p. 293-300.

[15] Schägger, H. and G. von Jagow, Tricine-sodium dodecyl sulfate-polyacrylamide gel electrophoresis for the separation of proteins in the range from 1 to $100 \mathrm{kDa}$. Analytical Biochemistry, 1987. 166(2): p. 368-379.

[16] Ahmed, H., principles and reactions of protein extraction, purification, and characterization, 2005.

[17] Electricwala, A., et al., Biochemical characterisation of a pancreatic elastase inhibitor from the leech Hirudinaria manillensis. Journal of enzyme inhibition, 1992. 6(4): p. 293-302.

[18] Electricwala, A., et al., Isolation of thrombin inhibitor from the leech Hirudinaria manillensis. Blood Coagul Fibrinolysis, 1991. 2(1): p. 83-9.

[19] Steiner, V., et al., Primary structure and function of novel O-glycosylated hirudins from the leech Hirudinaria Manillensis. Biochemistry, 1992. 31(8): p. 2294-8.

[20] Kordowicz, M.G., Detlef; Hofmann, Uwe; Pacuszka, Tadeusz; Gardas, Andrzej; , Hyaluronidase from the hirudinaria manillensis, isolation, purification and recombinant method of production 2000.

[21] Fink, E., et al., The primary structure of bdellin B-3 from the leech Hirudo medicinalis. Bdellin B-3 is a compact proteinase inhibitor of a "non-classical" Kazal type. It is present in the leech in a high molecular mass form. Biological chemistry Hoppe-Seyler, 1986. 367(12): p. 1235-42.

[22] Munro, R., C.P. Jones, and R.T. Sawyer, Calin--a platelet adhesion inhibitor from the saliva of the medicinal leech. Blood coagulation \& fibrinolysis : an international journal in haemostasis and thrombosis, 1991. 2(1): p. 179-84.

[23] Yuki, H. and W.H. Fishman, Purification and characterization of leech hyaluronic acidendo-beta-glucuronidase. The Journal of biological chemistry, 1963. 238: p. 1877-9.

[24] Baskova, I.P., et al., Separation of monomerizing and lysozyme activities of destabilase from medicinal leech salivary gland secretion. Biochemistry. Biokhimiia, 2001. 66(12): p. 1368-73.

[25] Bagdy, D., et al., [54] Hirudin, in Methods in Enzymology, L. Laszlo, Editor 1976, Academic Press. p. 669-678. 
[26] Baskova, I., et al., Proteins and peptides of the salivary gland secretion of medicinal leeches ;Hirudo verbana, H. medicinalis\&lt; and H. orientalis. Biochemistry (Moscow), 2008. 73(3): p. 315-320.

[27] Tuszynski, G.P., T.B. Gasic, and G.J. Gasic, Isolation and characterization of antistasin. An inhibitor of metastasis and coagulation. The Journal of biological chemistry, 1987. 262(20): p. 9718-23.

[28] Munro, R., C.P. Jones, and R.T. Sawyer, Calin-a platelet adhesion inhibitor from the saliva of the medicinal leech. Blood Coagulation \& Fibrinolysis, 1991. 2(1): p. 179-184. 